\title{
A Marketing Strategy Analysis of ATS Tour and Travel During Covid-19 Pandemic
}

\author{
Brian Ongko, I Dewa Gde Satrya* \\ Tourism Study Program, Ciputra University Surabaya, Indonesia \\ *Corresponding Author: dewa.gde@ciputra.ac.id \\ DOI: https://doi.org/10.24922/eot.v8i1.68935
}

\section{Article Info \\ Submitted \\ January $8^{\text {th }} 2021$ \\ Accepted \\ March $18^{\text {th }} 2021$ \\ Published \\ March $31^{\text {th }} 2021$}

\begin{abstract}
The spread of the Covid 19 Virus originating from China has made the world finally declare that this virus has become a pandemic status. One of the industries that have had a bad impact on the spread of this virus is tourism. Tour and Travel service providers that is struggling to survive this pandemic is ATS Tour and Travel. The problem experienced by the ATS Tour and Travel company today is the adjustment of the marketing strategy that will be used in the era of the pandemic that is affecting the world today. With these problems, the research was conducted qualitatively by interviewing 10 informants who were deemed to be representative to answer the problems that occurred during the Covid 19 pandemic. The results showed that in the indicators of crisis stages, ATS Tour and Travel had taken steps in all stages crisis well. In the indicator of disaster management, ATS Tour and Travel have also made its best efforts to prevent the impact of the COVID-19 pandemic, this includes health protocols that have been implemented, warning systems by only opening tourism in the green zone, informative media about Covid and tourist attractions that are not can be visited, disaster management by working with local guides and porters for site security and coordination. In the marketing strategy, it can be seen that currently, the target market for ATS Tour and Travel is changing, which initially served tour packages for foreign countries, is now starting to increase the domestic market.
\end{abstract}

Keywords: crisis stages, marketing strategy, disaster management, covid-19

\section{INTRODUCTION}

One of the industries that have had a bad impact on the spread of the coronavirus is tourism. One of the Tour and Travel companies that are struggling to survive this pandemic is ATS Tour and Travel. This company is based and established for the first time in Surabaya, East Java, Indonesia. This company was founded in 1992 with a focus as a travel service provider to the United States.

The problem experienced by the ATS Tour and Travel today is the adjustment of the marketing strategies used in the pandemic era that is befalling the world today. The intense competition in the pandemic era is also an issue that must be resolved by changing its marketing strategy. Tour and Travel companies are currently required to 
adjust to survive and of course, they must have a strategy that must be considered. In an era of a pandemic like this, Tour and Travel service providers are more applying strategies to survive the threat of bankruptcy compared to adding other sub-lines of business. One of the ways that must be done is by implementing a marketing strategy that is specially designed in conducting business defense (safety).

Salam, et al. (2019)) state that marketing strategy can be interpreted as a fundamental plan to achieve company goals by developing a competitive advantage, so that marketing strategies are not absolute, but can change at any time according to company needs. Therefore, this study focuses on the most appropriate marketing strategies for tour and travel companies, especially ATS Tour and Travel.

\section{LITERATURE REVIEW}

\section{Marketing Strategy}

Astuti and Kusumawati (2018) states that the tourism industry marketing strategy must be seen in the developed tourist behavior model. In this case, it means that the behaviour of tourists in choosing a tourist destination is influenced by internal aspects of the tourists themselves, such as demographics, social networks, personalities, values, experiences and attitudes of tourists, which in turn will form motives in choosing tourist destinations. . Furthermore, external aspects of a tourist destination such as attractiveness, sales methods, facilities, services, country/region as a destination host, the presence of other tourists, and tourist destination management can shape the image of a tourist destination.

Faisal and Arief (2017) state that marketing strategies can be implemented by tourism service provider companies as a real effort to maintain sales growth and possibly increase the following: Growing purchase motivation on potential customers or tourists; Offer minimal prices; Launch the promotion strategy.

Faisal and Arief (2017) state that sales have an important role in service marketing, because: Personal interaction between service providers and consumers is very important; The service is provided by people, not by machines; People are part of service products.

Kurniawan et al (2018) stated that the indicators of the marketing strategy are as follows: Market segmentation: is the process of dividing consumers into several classes based on several things such as character, needs and others. Market segmentation itself is intended to implement any activities provided by tourism service providers to consumers, this will provide better and more measurable services.

Target market is an effort to classify consumers according to the same characteristics and needs and become the company's promotional objectives. Market position: Kurniawan, et al. (2018) defines market positioning as a "strategy to direct customers" by building a sense of trust, confidence and competence for customers so as to create an existence in the minds of customers and lead them credibly.

\section{Tourism Disaster Management}

Basically, a crisis that hit the world economy can be resolved. With good management, all elements of the company and society can get through the crisis they are experiencing. Based on research conducted by Faulkner (2001), there is disaster management planning in tourism as follows. Protocol: is a clearly written set of emergency activities, what tourism authorizations must be obeyed and the rules that all elements must observe.

Disaster management centre: tourist attractions or tourism service providers must continue to coordinate with the disaster management command centre and provide all health facilities. 
Media and monitoring: the need for centralized media communication to provide appropriate and non-contradictory information. The role of the media, in this case, is to provide information to tourists about emergencies or the stage of recovery.

Warning system: Tour service providers and tourist attractions must coordinate the existing prohibitions and warnings regarding health and all the facilities in it. Coordination and approach: There is a need for testing of tourist attractions through coordination and approaches from tourist attractions to ensure that tourist attractions are safe to open.

Kasali (2013) states that there is a crisis management strategy model as follows: The pre-domal stage: is the initial stage which includes early detection of signs of an error in the system, but it turns out that it cannot be assumed that this can turn into a major crisis. Initial symptoms were detectable, but they could not be contained and resolved, resulting in a crisis. In this case, the crisis experienced is a crisis originating from an external source, namely the Covid 19 pandemic which has hit the entire world.

The acute stage appears when there are already many victims and the Indonesian government has implemented several regulations that have caused the tourism industry to slow down. The acute stage when the Covid 19 pandemic in Indonesia reached its peak and many tourists were afraid to travel.

Chronic stage: in this stage, it means that the conflict will end. In this phase, the crisis has found its bright point again. In this case, tourism service companies have begun to be able to create new marketing strategies in the middle of the new normal.

Choerunissa and Nugraha (2020) states, the analysis of the crisis management process is as follows: Crisis identification: the company should start reading and identifying the crisis. This must be strengthened through data such as the number of covid http://ojs.unud.ac.id/index.php/eot cases, cities that have been opened to the tourism industry and other things related to health protocols.

Crisis analysis: At this stage of crisis analysis, the company already has the data and is ready to execute it. In this case, in the new normal era, the Indonesian government has opened several areas where tourism activities are allowed. In this analysis stage, various advanced marketing strategies are also prepared to overcome the sluggish performance of the tourism industry.

Crisis isolation: the last crisis analysis is crisis isolation. In this case, the company must perform during the acute crisis stage. This is because when the pandemic crisis has become acute, companies must still have income and reserve funds for the sustainability of the company.

Surveillance marketing is marketing to survive, meaning that in difficult times a company runs its business operations what steps must be taken so that the company can survive and avoid bankruptcy. Gunagama, et al. (2020) stated that there are 3 recommendations that must be made by tourist service providers in the midst of the Covid-19 pandemic as follows: Crisis management and impact mitigation; The stage of providing stimulus and accelerating the healing; The stage for post-pandemic tourism preparation.

\section{METHODS}

In this study, researchers used a qualitative approach to obtain the desired research results. According to Sugiyono (2018), qualitative research is an exploratory process in understanding individual behaviour and can describe social problems in it. In this study, the researcher has two functions, the first being the researcher as a research instrument and the second being the researcher as the research evaluator.

Interviews were conducted online via video call. There are several factors that 
make researchers want to conduct research at the ATS Tour and Travel location: It is a large-scale company engaged in the tour and travel sector; It is a tour and travel company affected by the Covid 19 pandemic; It is a tour and travel company that survived the Covid 19 pandemic era; It is a tour and travel company with a range of tours to foreign countries.

The object in this research is ATS Tour and Travel, while the subject in this study is by conducting interviews with people who are considered to understand the problems in this study. The subjects who were the source of the data in this study were selected based on the considerations and objectives of the study. The object selected based on the research objectives will make it easier for researchers to explore the object to be studied. According to Yusanto (2020), qualitative methods also mean treating research sources as subjects and not objects. This is where the resource person can find himself as something of value. because the information is very useful in this study.

Triangulation is a method used in qualitative research to check and establish validity by analyzing data from various perspectives, each way from interviews and observations to data source triangulation will produce different evidence or data, which in turn will provide a different view of the phenomenon. researched (Sugiyono, 2018). The reliability test in this study was conducted by conducting semi-structured interviews as a data source. To support data reliability in this study, interview transcripts will be attached to the research report.

\section{RESULTS AND DISCUSSION}

Choerunnisa and Nugraha (2020) states that crises have a specific communication area, which includes external and internal aspects of the organization during crisis situations. In this study, the crisis that occurred was a coronavirus pandemic. Through the answers from internal and external informants, the condition of ATS Tour and Travel is like travel agents in general, which is not as good as before the Covid 19 pandemic. Octavianus as marketing director of ATS Tour and Travel stated that sales had decreased very drastically.

"The condition of the ATS company itself is certainly not much different from the conditions of other travel agents, where the condition of the company is not as good as before the Covid 19 pandemic" (BH-TK, F-1) "Now it is $99.9 \%$ there is no activity during the pandemic. " (IO-TK, H-1) Sandy Wahyudi, a marketing expert who became the informant for this study explained that in a pandemic, no good marketing strategy could change anything unless the company diversified its products.

"Actually, this covid pandemic hit the tourism industry and its derivatives the most, such as hotels, tourism travel, airlines, and many who have shifted shifts, such as Thailand Airways now selling fried food, then Air Asia has become a market place, hotels are starting to become offices for staycations for working from a hotel and so on. In my opinion, this is not always only a year, at least as long as the vaccine has not been found. The proof is that marketing is done with any effort still does not believe in travelling, so actually, even a great marketing strategy program will not be able to lift quickly if a business is only selling those products during the pandemic. For example, hotels only sell lodging, it won't work, so now many hotels are making virtual tours/ events and they rent even apologies for covid patient residences, like that is more or less so. during the pandemic can not only sell what the peacock a has been selling. " (SW-TK, e-ISSN 2407-392X. p-ISSN 2541-0857 


\section{I-1)}

Through the answers of the following informants, it can be understood that ATS Tour and Travel is a company that mainly operates a lot in the international market so that when the coronavirus becomes more widespread, the possibility to sell the international market is more difficult than the domestic market, so the step taken is to sell the market to domestic. The company external informants from this study argued that even though the government carried out the PSBB, it was still busy everywhere. It's just that many people are still afraid or paranoid so they don't want to travel.

"Actually, prior to this pandemic, ATS Vacation did not sell domestic product tours in series, but since the new Covid normal this month until now and so on, we continued to make domestic products, so previously there were no predictions, just following the developments." (BH-TA, F-5)

Through the informants' answers from ATS Tour and Travel consumers, they wanted a vacation that was not too far from Surabaya and not too crowded. Another informant stated that at this time he did not want to have a vacation abroad first, only wanted a vacation close to the city.

"I wish there was a virtual vacation like that or a less crowded vacation, places that many people rarely visit." (BL-TP, K-9)

Sandy Wahyudi stated that the public was aware of the new normal so that the many holidays like now (Christmas and New Year) are a harvest for the tourism industry.

"Last week I had a long holiday, took my family to Semarang, all the hotels in Semarang were full. So actually this travel tour has risen. Since August September it has started to harvest. October November even harvested again because of the long holiday Christmas and new years. actually, it's time to harvest because everyone understands that if you leave the house, wear a mask, bring a hand sanitiser, wash your hands. So it's actually jammed, Surabaya is jammed, my friend said in Jakarta is stuck. It's back to normal, so you don't have to immediately, yes, you have to run. Now is the right time to run. " (SW-TK, I-8)

According to an informant who came from ATS Tour and Travels consumers, he said he really wanted to go on vacation, but if the vaccine was found, the level of desire would be even more. He also gave his opinion that in the new normal era, he still wanted to do tourism activities as long as it was with health protocols.

"If I really have to go on vacation because of work stress, I want a tour package that maintains health and is in accordance with health protocols. And the distance is also not far. (KR -TP, M-9)

Through informants' answers from internal and external, that the health protocol is a campaign from ATS Tour and Travel. The company also guarantees that the buses to be used will be sprayed with disinfection every morning and restaurants for tourism activities have also been sterilized. Informants from consumers also added that the ATS Tour and Travel company maintains its staff by providing rapid services for every three months and providing boundaries between consumers and drivers in their tour vehicles.

"Of course we have done this for the health protocol, we have done it, we keep encouraging this health protocol to guests, so we continue to emphasize it like that. Currently, besides telling us what the contents of the product are like, we mean where we go, the tour is in whichever is so, we also emphasize that this trip is safe with health and hygiene, such as e-ISSN 2407-392X. p-ISSN 2541-0857 
buses that are disinfected every morning, and also restaurants and hotels that already have certification for cleaning the safety of their comfort. " (BH-PK, F-10)

"So most of us still follow up via WhatsApp, telephone, payments are mostly cashless, transfers for EDC are all kinds of things. We also have a platform for online payments too, so we limit our touches, direct contact with staff." (OC-PK, G-13)

"For our consumers, we don't know exactly, it is only the covid SOP from the office, so, for example, the vehicle that belongs to me is all for the shuttle, there is a barrier between the driver and the passenger, while the passengers who ride us don't ask for rapid tests and so on, so we don't know. rapid test or not. What is certain is that for the crew, do it 3 times a month quickly. " (IO-PK, H-12)

The expert who became an informant in this study stated that Tour and Travel companies must include travel costs with all matters related to health protocols such as face shields, hand sanitisers and masks.

"That's related to cost, sometimes there are travel tours that include the cost of the trip with a hand sanitiser, with a face shield, with the rapid test included in the plane ticket, that's also a bonus for consumers. But maybe there are consumers who are more comfortable bringing their own equipment, face Shield or mask itself. So it's optional if you want a bundling ticket including the protocol equipment, how much you don't have to bring it yourself, I don 't have to include it, I guess. " (SW-PK, I-10)

According to consumers in this study, when Tour and Travel included travel costs with a rapid test, it was very helpful for them to go on vacation.
"In my opinion, at least they provide a rapid test facility before leaving and it has become a package with the price of the travel. It's fine in my opinion. " $(R W-P K, N-10)$

\section{CONCLUSION}

When it is viewed in the indicators of crisis stages, ATS Tour and Travel has taken steps in all stages of the crisis properly. ATS Tour and Travel has detected the influence of Covid-19 on the tourism industry and has made every effort to reduce the impact of the crisis.

In indicators of disaster management, ATS Tour and Travel have also made its best efforts to prevent the impact of the Covid-19 pandemic, including, implemented health protocols, warning systems by only opening tourism in the green zone, informative media about Covid-19 and tourist attractions which should not be visited, disaster management by working with local guides and porters for location security and coordination. In this indicator, only one sub-indicator is considered lacking, namely the protocol indicator. Many consumers expect the price offered to be included in the rapid test package when leaving because this can shorten and simplify tourist time.

In the marketing strategy, it can be seen that currently the target market of ATS Tour and Travel has changed, which initially served tour packages for foreign countries, is now starting to increase the domestic market. However, in terms of market segmentation, currently, ATS Tour and Travel has not changed much because most of its consumers are still middle and upperclass consumers who continue to prioritize comfort when travelling, even though only domestically.

\section{REFERENCES}

Astuti, W.P. and Kusumawati, A., (2018). 
Upaya Pemasaran Pariwisata Ponorogo Melalui City Branding Dalam Meningkatkan Kunjungan Wisatawan (Studi Kasus pada City Branding Kabupaten Ponorogo dengan Tagline "Ethnic Art of Java. Jurnal Administrasi Bisnis, 55(1), pp.48-58.

Choerunnisa, S. and Nugraha, A.R., (2020). Strategi Manajemen Krisis Humas Pln Uid Jabar Dalam Menangani Blackout Jaringan Jawa Bagian Tengah. Communiverse: Jurnal Ilmu Komunikasi, 5(2), pp.137-150.

Faisal, M. and Arief,A.M.R., (2017). Pelaksanaan Bauran Promosi Paket Wisata di PT. Urbanitas Tour and Travel Pekanbaru Riau (Doctoral dissertation, Riau University).

Faulkner, B. (2001). Towards a framework for tourism disaster management, Tourism management, 22(2), pp. 135147.

Gunagama, M. G., Naurah, Y. R. and Prabono, A. E. P. (2020). Pariwisata Pascapandemi: Pelajaran Penting dan Prospek Pengembangan, LOSARI: Ju- rnal Arsitektur Kota dan Pemukiman, pp. 56-68.

Kasali, R. (2013). Marketing In Crisis. Gramedia Pustaka Utama.

Kurniawan, A.W., Hasiholan, L.B. and Malik, D., (2018). Strategi Pemasaran Dan Rencana Pengembangan Rumah Makan (Studi Deskriptif Kualitatif Strategi Pemasaran dan Rencana Pengembangan Omah Roso Resto and Café di Cabang Baru Pemuda Semarang)', Journal of Management, 4(4).

Salam, H.I., Widodo, J. and Zulianto, M., (2019). Strategi Pemasaran Pada Pt Nuansa Wisata Prima Nusantara Tour \& Travel Jember. Jurnal Pendidikan Ekonomi: Jurnal Ilmiah Ilmu Pendidikan, Ilmu Ekonomi Dan Ilmu Sosial, 13(1), pp.66-71.

Sugiyono. (2018). Metode Penelitian Kuantitatif, Kualitatif, dan $R \& D$. Bandung: Alfabeta.

Yusanto, Y. (2020). Ragam Pendekatan Penelitian Kualitatif', Journal of Scientific Communication (JSC), 1(1). 